\title{
Randomised studies of income supplementation: a lost opportunity to assess health outcomes
}

\author{
Jennie Connor, Anthony Rodgers, Patricia Priest
}

\begin{abstract}
Background-Despite the wealth of evidence linking low income to ill health, there is little information from randomised studies on how much and how quickly these risks can be reversed by improvements in income.
\end{abstract}

Objective-To conduct a systematic review of randomised studies of income supplementation, with particular reference to health outcomes.

Design-Extensive searches of electronic databases and contact with previous authors. As well as searching for trials that were specifically designed to assess the effects of increased income, studies of winners and losers of lotteries were also sought: if winning is purely chance, such studies are, in effect, randomised trials of increased income.

Results-Ten relevant studies were identified, all conducted in North America, mostly in the late 1960 s and 1970s. Five trials were designed to assess the effects of income supplementation on workforce participation and randomised a total of 10000 families to 3-5 years of various combinations of minimum income guarantees and reduced tax rates. Two trials were designed to assess re-offending rates in recently released prisoners and randomised a total of 2400 people to 3-6 months of benefits. One trial was designed to assess housing allowances and randomised 3500 families to three years of income supplements. One trial assessed the health effects of 12 months of income supplementation in $\mathbf{5 4}$ people with severe mental illness. Finally, one study compared three groups of people who won different amounts of money in a state lottery. In all these studies the interventions resulted in increases in income of at least one fifth. However, no reliable analyses of health outcome data are available.

Conclusions-Extensive opportunities to reliably assess the effects of increases in income on health outcomes have been missed. Such evidence might have increased the consideration of potential health effects during deliberations about policies that have major implications for income, such as taxation rates, benefit policies, and minimum wage levels. Randomised evidence could still be obtained with innovative new studies, such as trials of full benefit uptake or prospective studies of lottery winners in which different sized winnings are paid in monthly instalments over many years.

(F Epidemiol Community Health 1999;53:725-730)
The relation between low socioeconomic circumstances and the risks of poor health is well established..$^{1-3}$ Income is an important component of socioeconomic status (SES) and is independently associated with a wide range of health status measures. ${ }^{3}$ Furthermore, income is frequently manipulated by changes in public policy, such as taxation rates, benefit policies and minimum wage levels. There is little indication that potential changes in health status are routinely considered in decisions about implementation of such policies. The purpose of this review was therefore to discover what experimental evidence exists on how much and how quickly the risks of poor health can be reversed by improvements in income. Two main sources of such evidence were anticipated. Firstly, trials that were designed to assess the effects of increased income on outcomes such as workforce participation. Secondly, studies of lottery participants: if lottery winners are compared with non-winning ticket buyers, with the number and types of tickets bought taken into account, these studies are, in effect, randomised trials of increased income.

\section{Methods}

We sought to identify all randomised controlled studies in which there was allocation to different levels of income. Trials were not eligible if payment was explicitly linked to some behaviour modification (for example, incentive payments ${ }^{4}$ ), if payment could only be spent in a certain way (for example, vouchers ${ }^{5}$ ), if the control group had some other intervention (for example, Foodstamps Cashout Trials ${ }^{6}$ ), if there was allocation to services that usually cost money (for example, the RAND health insurance experiment ${ }^{7}$ ), or if there was allocation to interventions that potentially increased future income (such as employment assistance, for example, the JOBS study, ${ }^{8}$ or early childhood education, for example, the Highscope study ${ }^{9}$ ).

A number of computerised databases were searched: Current Contents (1995-1997), Embase (Excerpta Medica) (1980-1997), Medline (1966-1997), PAIS (Public Affairs Information Service) International (19721997), PsycLit (1974-1997), Social Science Index (1984-1997), Sociofile (1974-1997), EconLit (1969-1996), IBSS (International Bibliography of the Social Sciences, 19791997), Dissertation Abstracts (1988-1997), and The Cochrane Library (1997, issue 3). Search terms included income, income tax, experiment, randomised or randomised, social experimentation, health status, lottery, windfall, and subsidy. The author's names and study titles from relevant reports were also 


\begin{tabular}{|c|c|c|c|c|c|}
\hline Study or group of studies & Start year & Major target group $(s)$ & Allocation method & Sample size & Intervention \\
\hline \multicolumn{6}{|c|}{ North American income maintenance experiments } \\
\hline $\begin{array}{l}\text { New Jersey/Pennsylvania Income } \\
\text { Maintenance Experiment (GWIE) }\end{array}$ & 1968 & $\begin{array}{l}\text { Low-income, } 2 \text { parent } \\
\text { families }\end{array}$ & $\begin{array}{l}\text { Conlisk-Watts } \\
\text { model }\end{array}$ & $\begin{array}{l}725 \text { study } \\
632 \text { controls (families) }\end{array}$ & Negative income tax plans \\
\hline $\begin{array}{l}\text { Rural Income Maintenance } \\
\text { Experiment (RIME) }\end{array}$ & 1970 & $\begin{array}{l}\text { Low-income, } 2 \text { parent } \\
\text { families }(85 \%) \\
\text { Low-income, } 1 \text { parent } \\
\text { families }(15 \%)\end{array}$ & $\begin{array}{l}\text { Conlisk-Watts } \\
\text { model }\end{array}$ & $\begin{array}{l}372 \text { study } \\
437 \text { controls (families) }\end{array}$ & Negative income tax plans \\
\hline $\begin{array}{l}\text { Gary Income Maintenance } \\
\text { Experiment (GIME) }\end{array}$ & 1971 & $\begin{array}{l}\text { Low-income, } 2 \text { parent } \\
\text { black families }(41 \%) \\
\text { Low-income, } 1 \text { parent } \\
\text { black families }(59 \%)\end{array}$ & $\begin{array}{l}\text { Conlisk-Watts } \\
\text { model }\end{array}$ & $\begin{array}{l}1028 \text { study } \\
771 \text { controls }\end{array}$ & $\begin{array}{l}\text { Negative income tax plans } \\
\text { Daycare subsidies }\end{array}$ \\
\hline $\begin{array}{l}\text { Seattle/Denver Income Maintenance } \\
\text { Experiment (SIME/DIME) }\end{array}$ & 1971 & $\begin{array}{l}\text { Low-income, } 2 \text { parent } \\
\text { families }(61 \%) \\
\text { Low-income, } 1 \text { parent } \\
\text { families }(39 \%)\end{array}$ & $\begin{array}{l}\text { Conlisk-Watts } \\
\text { model }\end{array}$ & $\begin{array}{l}2747 \text { study } \\
2053 \text { controls (families) }\end{array}$ & $\begin{array}{l}\text { Negative income tax plans } \\
\text { Employment counselling } \\
\text { Educational subsidies }\end{array}$ \\
\hline $\begin{array}{l}\text { Manitoba Basic Annual Income } \\
\text { Experiment (Mincome) }\end{array}$ & 1975 & $\begin{array}{l}\text { Low-income } 1 \text { - and 2- } \\
\text { parent families }\end{array}$ & $\begin{array}{l}\text { Conlisk-Watts } \\
\text { model (modified) }\end{array}$ & $\begin{array}{l}\text { >1300 families } \\
\text { Winnipeg: } \\
575 \text { study } \\
612 \text { controls }\end{array}$ & Negative income tax plans \\
\hline \multicolumn{6}{|c|}{ Financial assistance to ex-prisoners } \\
\hline $\begin{array}{l}\text { Living Insurance for ex-offenders } \\
\text { (LIFE) }\end{array}$ & 1973 & $\begin{array}{l}\text { Repeat theft offenders } \\
\text { released from Maryland } \\
\text { prisons }\end{array}$ & $\begin{array}{l}\text { Stratified } \\
\text { randomisation }\end{array}$ & $\begin{array}{l}216 \text { study } \\
216 \text { controls }\end{array}$ & $\begin{array}{l}\text { Weekly cash transfers } \\
\text { Job placement services }\end{array}$ \\
\hline $\begin{array}{l}\text { Transition Aid Research Project } \\
\text { (TARP) }\end{array}$ & 1976 & $\begin{array}{l}\text { Released prisoners } \\
\text { from Georgia and } \\
\text { Texas }\end{array}$ & $\begin{array}{l}\text { Stratified } \\
\text { randomisation }\end{array}$ & $\begin{array}{l}1551 \text { study } \\
400 \text { controls (Record linkage for } \\
\text { additional } 2031 \text { controls) }\end{array}$ & $\begin{array}{l}\text { Weekly cash transfers } \\
\text { Job placement services }\end{array}$ \\
\hline $\begin{array}{l}\text { Housing allowances } \\
\text { Experimental Housing Allowance } \\
\text { Program: Demand Experiment } \\
\text { (EHAP) }\end{array}$ & 1973 & $\begin{array}{l}\text { Low-income renter } \\
\text { households }\end{array}$ & $\begin{array}{l}\text { Method of } \\
\text { randomisation not } \\
\text { stated }\end{array}$ & $\begin{array}{l}2466 \text { study (in } 17 \text { groups) } \\
1100 \text { controls (in } 2 \text { groups) }\end{array}$ & Housing allowances \\
\hline $\begin{array}{l}\text { Mental health } \\
\text { Partnerships for people with } \\
\text { serious mental illness who live } \\
\text { below the poverty line }\end{array}$ & 1992 & $\begin{array}{l}\text { People with severe and } \\
\text { persistent mental illness } \\
\text { living in poverty }\end{array}$ & Envelope method & $\begin{array}{l}26 \text { study } \\
22 \text { controls } \\
54 \text { randomised }\end{array}$ & $\begin{array}{l}\text { Monthly cash allowances and } \\
\text { forgivable loans for a year } \\
\text { Support and advice }\end{array}$ \\
\hline $\begin{array}{l}\text { Lottery } \\
\quad \text { Massachusetts State Lottery }\end{array}$ & 1984 & Lottery ticket buyers & Not available & $\begin{array}{l}259,129 \text { and } 108 \text { "losers", small } \\
\text { and big winners, respectively }\end{array}$ & $\begin{array}{l}\text { Small, one-off prizes } v 20 \\
\text { larger annual payments }\end{array}$ \\
\hline
\end{tabular}

subsequently used as search terms. No language restrictions were used. The reference lists of all papers identified by the search were scrutinised for additional studies. Additionally, the internet sites and publication lists of institutions involved in the design, conduct and analysis of the studies were searched. Lastly, contact was attempted with investigators, institutions and funding agencies involved in all potentially eligible studies. Data on any health outcomes were sought and original data obtained where possible.

\section{Results}

The combined search strategies identified 10 eligible studies (see table 1). All but two of the studies were social experiments carried out in North America that aimed to assess the effects of alternative welfare policies.

INCOME MAINTENANCE EXPERIMENTS

Four large trials in the US and one in Canada were carried out to assess the impact of a guaranteed minimum income on the "labour supply" (that is, workforce participation) of poor families. This issue was central to proposals to replace the complex set of welfare entitlements with a single cash benefit that would diminish as earnings increased. ${ }^{10}$ The basic intervention was a combination of a minimum income guarantee and a variable tax rate on earned income. Over 10 thousand low income families in a variety of settings were allocated by the Conlisk-Watts assignment model to many different combinations of income maintenance or to control groups. ${ }^{11-13}$ Payments continued for 3-5 years and averaged between about two fifths and four fifths of pre-experimental income.

Very few health outcome data were collected in these trials and even fewer reported. Microfiches of the original data were obtained from the National Archives and Records Administration (NARA) but most were unreadable (including the health data for SIME/DIME), no health related data had been archived from the New Jersey or Gary experiments and no data had been archived from the Rural experiment. Additionally, for a number of reasons related to the Conlisk-Watts assignment model, these studies did not provide properly randomised comparisons. Families were allocated to different groups according to complex models that depended on estimated annual income, family size and occasionally other factors such as race, and that aimed to maximise the number of families enrolled-that is, a higher proportion of poorer families went into the least generous plans. ${ }^{14}$ Despite the fact that allocation was related to pre-experimental income and other confounders, with major implications for the estimation of experimental effects, ${ }^{11-13}$ the stratification variables were often not included in the analyses. ${ }^{11} 1415$ Furthermore, response and follow up rates were inversely related to the generosity of the interventions. ${ }^{16-18}$

Income maintenance was reported to modestly decrease workforce participation. ${ }^{19-24}$ There were no consistent effects on other 
Table 1 continued

\begin{tabular}{|c|c|c|c|}
\hline Duration & $\begin{array}{l}\text { Mean annual payments } \\
\text { (1996 US \$) }\end{array}$ & $\begin{array}{l}\text { Payment as \% of } \\
\text { base income }\end{array}$ & Major outcomes of interest \\
\hline 3 years & 4800 & $23 \%$ & $\begin{array}{l}\text { Workforce participation } \\
\text { Consumption patterns }\end{array}$ \\
\hline 3 years & $5900-6800$ & $25-44 \%$ & Workforce participation \\
\hline 3 years & 9500 & $45 \%$ & $\begin{array}{l}\text { Workforce participation } \\
\text { Utilisation of day care }\end{array}$ \\
\hline $\begin{array}{l}3 \text { years } \\
5 \text { years }\end{array}$ & $\begin{array}{l}10500(2 \text { parent }) \\
8100(1 \text { parent })\end{array}$ & $42 \%$ (2 parent) & $\begin{array}{l}\text { Workforce participation } \\
\text { Marital stability }\end{array}$ \\
\hline 3 years & Not available & Not available & Workforce participation \\
\hline 13 weeks & 11000 & No base income & $\begin{array}{l}\text { Earnings } \\
\text { Re-offending }\end{array}$ \\
\hline $\begin{array}{l}13 \text { weeks } \\
26 \text { weeks }\end{array}$ & $9000-10000$ & No base income & $\begin{array}{l}\text { Re-offending } \\
\text { Employment } \\
\text { Earnings }\end{array}$ \\
\hline 3 years & 3000 & $25 \%$ & $\begin{array}{l}\text { Participation rates } \\
\text { Use of housing allowances } \\
\text { Housing quality }\end{array}$ \\
\hline 1 year & 3600 & $34 \%$ & $\begin{array}{l}\text { Re-admission rates } \\
\text { Quality of life scores }\end{array}$ \\
\hline $\begin{array}{l}\text { Follow up to } \\
1994\end{array}$ & $\begin{array}{l}\text { One off } \$ 150-7500 v \\
\$ 30000 \text { per year } v \\
\$ 150000 \text { per year }\end{array}$ & $140-800 \%$ & Workforce participation \\
\hline
\end{tabular}

outcomes that would affect health indirectly, such as marital stability, nutrition or education, and these findings are described in detail elsewhere. ${ }^{15} 0^{25-32}$ The few data available on health outcomes and health care are summarised below.

New fersey- Pennsylvania Negative Income Tax Experiment

Information on health and medical care utilisation from this study was included in The Final Report from this project, but only for the $55 \%$ of participants who were in stable families and who completed the whole experiment. ${ }^{33} 34$ No statistically significant treatment effect was reported for chronic illnesses, hospital days, work days lost, or physician visits, but a possible increase in doctor's visits for children early in the experiment was reported. An alternative analysis in The Final Report ${ }^{35}$ found that the experimental payments were associated with significantly altered patterns of medical care utilisation, which also varied with health insurance status, but that there was no significant effect on health status indicators (days in bed, days not working, illness lasting more than three months, illness interfering with work or illness preventing work). Finally an overview of the results on consumption, health and social behaviour in the Final Report, and reproduced elsewhere, ${ }^{27}$ reports no significant findings for health, and that extra income was used in generally the same way as pre-experimental income resulting in a small improvement in housing and material standard of living.
KEY POINTS

- There have been large, randomised trials of income supplementation, with substantial payments made for months or years.

- The trials were not designed with a health focus (for example, some primarily assessed workforce participation) and opportunities to assess health outcomes were missed.

- Randomised evidence could be obtained with innovative new studies, such as prospective studies of lottery winners.

The Rural Income Maintenance Experiment No reports on health or medical care utilisation from this study were published in refereed journals. The Final Report contains an analysis by Kerachsky, ${ }^{36}$ also available from the study contractors Mathematica Policy Research Inc, ${ }^{37}$ using the same methodology as in the New Jersey experiment, which found no significant effects for either medical care utilisation or health status. Women and children in experimental groups reported increases in the presence of illness, but total expenditure on medical care was not clearly different from controls. Measures of psychological well being used in this study found a few scattered and inconsistent effects. ${ }^{20}$

The Gary Income Maintenance Experiment The findings for low birth weight in this trial ${ }^{38}$ seem to be the only health information reported in the peer reviewed literature and have been widely cited. The analysis of the experimental effect on birth weight was based on 404 single live births, identified retrospectively, with 256 in experimental families and 148 in controls. The mean birth weight for the treatment group infants was $3147 \mathrm{~g}$ and for controls it was $3173 \mathrm{~g}$. The sample of 404 was divided into 12 "cohorts" of mothers on the basis of age $(<18,18-34,>34)$, interval since last birth (<16 months, $>16$ months) and smoking status. The numbers in each subgroup are not given but must average 21 for the intervention group and 12 for controls, and are likely to be smaller in the $<18$ and $>34$ age groups. The analysis reported a statistically significant $(p<0.05$ or $p<0.01)$ improvement in birth weight in the experimental subgroups with three risk factors and in some subgroups with two. It also reported a significant $(p<0.01)$ decrease in the birth weight of subjects in the lowest risk group, that is the 18-34 year old non-smokers with a longer than 16 month birth interval. The researchers reported no difference in the frequency or type of prenatal care received by experimental and control mothers. ${ }^{39}$

Seattle/Denver Income Maintenance Experiment The Final Report of the SIME/DIME experiment $^{15}$ summarised findings on health and medical care utilisation from unpublished analyses, ${ }^{40}$ effects on psychological distress, ${ }^{41}$ and effects on birth weight. A 
more comprehensive range of health related measures was used than in previous experiments, including work days lost because of illness, number of hospitalisations, hospital days, work days missed in the past six months, functional limitation in household tasks, presence of a chronic condition limiting daily living or work, duration of condition, a mental health index, and a subjective health assessment.

The authors reported a decrease in hospital days for men, improvement in mental health index for wives, and reduction in duration of chronic illness for female family heads. The authors conclude that the experimental treatments probably did not affect the health of participants significantly. For most groups there was no observable experimental effect on psychological distress levels. Most of the scattered subgroup effects indicated an increase in distress levels, and offered no support for the idea that the income guarantee increased psychological well being. The effect of the experiment on low birth weight was studied in the Denver sample, but the results were not widely disseminated. ${ }^{42}$ No experimental effect was reported for babies $2500 \mathrm{~g}$ or less. Repeat analyses using the definition for low birth weight from the Gary experiment (3000 g or less) reported a significant improvement in the low risk subgroup of Chicano women who did not smoke and did not have a short birth interval. ${ }^{15}$ An increase in medical care expenditures was reported of $28 \%$ in two parent families and $40 \%$ in single parent families.

\section{The Manitoba Basic Annual Income Experiment (Mincome)}

No health related data have been reported from the Mincome experiment. Plans to include health status measures including birth weight, head circumference (at birth), and nutritional status were dropped because the sample was considered too small to demonstrate significant differences (Hum D, personal communication).

FINANCIAL ASSISTANCE TO EX-PRISONERS

The Living Insurance For Ex-offenders (LIFE) project and Transitional Aid Research Project (TARP) recruited prisoners about to be released from prison in the USA, and aimed to assess the effect of regular income on rates of re-offending, employment, and earnings. ${ }^{43}$ Overall, approximately 2400 people were randomised. Payments were made for 13 or 26 weeks at a rate $10-30 \%$ above the poverty threshold. The LIFE project, which only included subjects estimated to be at high risk of re-offending, reported a reduction in property offences, but the larger TARP study showed no clear effect on criminal activity. No health outcome information was collected in either study and, for TARP, this was confirmed after examining the original data.

THE EXPERIMENTAL HOUSING ALLOWANCE PROGRAM

The Experimental Housing Allowance Program (EHAP) was conducted to inform the debate over the use of housing allowances as a substitute for public housing to low income families in the USA. The Demand experiment was one component of EHAP in which 3500 low income renter families were randomised to a variety of experimental housing assistance delivery plans or a control group. Several plans involved unconstrained cash payments and thus represented increased family income. ${ }^{44}$ Payments averaged about one quarter of pre-experimental income for three years. Reported improvements in housing quality were small and did not vary greatly with the type of payment made. ${ }^{45}$ No health outcome information was collected and all original data have since been inadvertently destroyed (Shroder $\mathrm{M}$, personal communication).

MENTAL HEALTH STUDIES

The only study included in the review that was primarily designed to assess the links between poverty and health was a Canadian study of 54 people with serious mental illness who were living below the poverty line. ${ }^{46}$ Twenty six participants were randomised to receive allowances and forgivable loans to raise them above the poverty line for one year. All participants selected one staff member from a consortium of supporting agencies to serve as a sponsor and another person to serve as an advisor. Compared with baseline, in both groups hospitalisation rates decreased substantially and quality of life improved in some domains (finances, mental and physical health). There was no clear difference in the response of the two groups, but the small sample size meant that moderate sized differences could not be excluded.

\section{LOTTERY STUDIES}

Imbens et al (personal communication) surveyed winners of the Massachusetts State Lottery in the mid-1980s with the aim of assessing the effects of winning on labour supply and subsequent earnings. The "control" group was 259 season ticket holders who won comparatively small one off payments of $\$ 150-\$ 7500$ (adjusted to 1996 US dollars). Two study groups were identified: 129 people who won less than $\$ 53000$ per year (average $=\$ 30000$ per year) for 20 years and 108 people who won more than $\$ 53000$ per year (average = $\$ 150000$ per year) for 20 years. Although the chances of any given ticket winning were equal, there were three factors that may have affected baseline comparability between the study and control groups. Firstly, the control group was season ticket holders while the study groups included season ticket and regular ticket holders. Secondly, survey response rates were $49 \%$ for the control group and $42 \%$ for the study groups. Thirdly, there may have been confounding by number of tickets bought and hence probability of winning. Overall, there was clear evidence that at baseline the control group participants had higher earnings, were older, better educated and bought fewer tickets. However, there were only very small differences between the two study groups. After taking these factors into account, the authors reported that only those winning more 
than $\$ 53000$ per year reduced their labour supply substantially. No health outcome data were collected.

\section{Discussion}

Evidence from observational studies is convincing that poverty is a powerful cause of ill health. The studies reviewed here could have provided reliable evidence on the speed and extent to which the risks of poor health are reversed by income supplementation. However, they are uninformative in this regard, principally because health outcome data were not collected rather than a lack of relevant studies: 10 randomised studies of income supplementation were identified and, although follow up was short there were relatively large numbers in total and proportional increases in income of at least one fifth. In particular, reliable conclusions from the large North American income maintenance trials concerning health outcomes are not possible because of lack of data and major shortcomings in design and analysis.

A systematic review should identify, collate, appraise and, if appropriate, combine results from similar studies. ${ }^{47}$ Problems with one or more aspects of data collection, storage, and analysis of the individual studies prevented the last step occurring for this review and a formal numeric meta analysis was not performed. The narrow focus of this review on randomised trials of income supplementation and health outcomes was taken for several reasons. Firstly, randomisation improves the reliability of results. Secondly, income is an easily identifiable and theoretically modifiable component of SES. Thirdly, health outcomes were chosen rather than extent of health care utilisation because the latter is likely to be determined by both need and ability to pay. Lastly, for reasons of manageability, the review did not attempt to summarise the many thousands of other relevant studies, including observational studies of individuals, studies of societal factors such as the gap between rich and poor, and trials that involve other components of SES.

Experimental evaluation of social policies is controversial. ${ }^{48-51}$ In particular in this case, the balance between the costs and consequences of policies to increase income might be quite different at the individual and societal levels. However, the controversies surrounding experiments should be viewed in light of the fact that substantial changes in income are already made by governments via taxation, benefits, etc. Moreover, these changes are made in an unsystematic way so their effects on, for example, health, cannot be evaluated reliably.

This review has shown that randomised trials of income supplementation have been done but the opportunities to assess the effects on health outcomes were missed. For a number of reasons, including their enormous cost, ${ }^{52}$ the income maintenance experiments are unlikely to be repeated, but innovative alternatives are possible. For example, as large amounts of social welfare benefits go unclaimed, ${ }^{53}$ potential recipients could be randomised to additional advice and assistance in obtaining a full entitlement. Another realistic alternative is to use the randomisation process inherent in lotteries, as demonstrated in the Massachusetts State Lottery study reported here. For example, a prospective study of winners, in which different sized monthly instalments of lottery winnings were made in return for completion of a questionnaire, would, in effect, be a randomised trial of more compared with less income supplementation. It would therefore be able to reliably assess the effects of increased income on health. Although such studies would involve some sacrifice of applicability for reliability and be less pertinent to policy on the structural determinants of income inequality, they could still provide some evidence relevant to policies affecting income at an individual level. If the findings were positive they would provide a powerful incentive to increase the consideration of potential changes in health status during policy deliberations on taxation, benefits and minimum wage levels.

Information on original studies was given by Mark Bendick Jr (EHAP and RAND), Glen Cain (RIME), Gary Gerber (Mental health study), Derek Hum (Mincome), Guido Imbens (Massachusetts State Lottery study), Maurice Macdonald (Foodstamps), Joseph Newhouse (RAND), Jim Ohls (Foodstamps), Peter Rossi (LIFE, TARP, GWIE, SIME/DIME), Mark Shroder
(EHAP) and Raymond Struyk. Help with searches was provided (EHAP) and Raymond Struyk. Help with searches was provided by Center for Electronic Records archivists at National Archives
and Records Administration (USA), Carolyn Estey (Stanford and Records Administration (USA), Carolyn Estey (Stanford
Research Institute), Bert Penn (Institute for Research on Research Institute), Bert Penn (Institute for Research on
Poverty), Joanne Pfleiderer (Mathematica Policy Research). The authors would like to acknowledge the help of the many people who commented on early drafts of the paper. Jennie Connor is an epidemiology training fellow with the Australasian Faculty of Public Health Medicine and Patricia Priest is an Oxford Nuffield Medical Fellow.

Funding: this work was made possible by grants from the Health Research Council of New Zealand.

Conflicts of interest: none.

1 Davey Smith G, Bartley M, Blane D. The Black report on socioeconomic inequalities in health 10 years on. BMF 1990;301:373-7.

2 Adler $\mathrm{N}$, Boyce $\mathrm{T}$, Chesney $\mathrm{M}$, et al. Socioeconomic inequalities in health: no easy solution. $\mathcal{F} A M A 1993 ; 269$ 3140-5.

3 McDonough P, Duncan G, Williams D, et al. Income dynamics and adult mortality in the United States, 1972 through 1989. Am f Public Health 1997;87:1476-83.

4 Stevens-Simon C, Dolgan J, Kelly L, et al. The effect of monetary incentives and peer support groups on repeat dolescent pregnancies. A randomized trial of the Dollar-aday Program. $\mathscr{f} A M A$ 1997;277:977-82.

5 Skaer T, Robison L, Sclar D, et al. Financial incentive and the use of mammography among Hispanic migrants to the United States. Health Care for Women International 1996;17: 281-91.

6 Fraker T, Martini A, Ohls J. The effect of food stamp cashout on food expenditures: an assessment of findings from four evaluations. Fournal of Human Resources 1995;30:633-

7 Newhouse J. Free for all? Lessons from the RAND Health Insurance Experiment. Cambridge (MA): Harvard University Press, 1993.

8 Vinokur A, Van Ryn M, Gramlich E, et al. Longterm follow-up and cost-benefit analysis of the JOBS Program: A preventive intervention for the unemployed. F Appl Psychol preventive interve

9 Schweinhart L, Weikart D. A summary of significant benefits: the Highscope Perry preschool study through age 27. Ypsilanti (MI):Highscope Press, 1993

10 Munnell AH. An Overview. In: Munnell AH, ed. Lessons from the Income Maintenance Experiments. Boston: Federal Reserve Bank of Boston, 1986:1-21.

11 Basilevsky A, Hum D. Experimental social programs and analytic methods. An evaluation of the US Income Maintenance Projects. Orlando: Academic Press, 1984

12 Conlisk J. Design model issues in social experimentation. fournal of Human Resources 1986;21:563-85.

13 Keeley MC, Robins PK. Experimental design, the ConliskWatts Assignment Model, and the proper estimation of behavioral response. Fournal of Human Resources 1980;15: 480-98.

14 Burtless G. The work response to a guaranteed income: a survey of experimental evidence. In: Munnell A, ed. Lessons from the Income Maintenance Experiments. Boston: Federal Reserve Bank of Boston, 1987:32-3. 
15 Davis MR, Kehrer K. Overview of research on health, consumption, and social behaviour. In: Final Report of the Seattle-Denver Income Maintenance Exp DC: US Department of Health and Human Services, 1983:387-447.

16 Hum D, Simpson W. Economic response to a guaranteed annual income: experience from Canada and the United States. Fournal of Labor Economics 1993;11:S263-96.

17 Ashenfelter O, Plant M. Nonparametric estimates of the labor-supply effects of negative income tax programs. fournal of Labor Economics 1990;8:S397-415.

18 Zellner A, Rossi P. Evaluating the methodology of social experiments. In: Munnell A, ed. Lessons from the Income Maintenance Experiments. Boston: Federal Reserve Bank of Boston, 1987:131-57.

19 Robins PK. The labor supply response of twenty-year families in the Denver income maintenance experiment. Review of Economics and Statistics 1984;66:491-5.

20 US Department of Health Education and Welfare. Summary Report: Rural Income Maintenance Experiment. Mary Report: Rural Income Maintenance Experiment. No. SR10.

21 US Department of Heath and Human Services. Overview of the Seattle-Denver Income Maintenance Experiment Final Report. Washington DC: Office of Income Security Policy, May 1983.

22 Rees A. An overview of the labor-supply results. Fournal of Human Resources 1974; IX:158-80.

23 Moffitt R. The labor supply response in the Gary Experiment. Fournal of Human Resources 1979;XIV:47787.

24 Hum DPJ, Choudhry S. Income, work and marital dissolution: Canadian experimental evidence. fournal of Comparative Family Studies 1992;23:249-65.

25 Hanushek E. Non-labor-supply responses to the income maintenance experiments. In: Munnell $\mathrm{A}$, ed. Lessons from Reserve Bank of Boston, 1987:106-30.

26 Mallar C, Maynard R. An overview of the analyses of the effects of the rural and New fersey Income Maintenance Experiments of the rural and New fersey Income Maintenance Experiments
on school performance and educational attainment. Staff Paper. on school performance and educational attainment. Staff Paper.
Princeton: Mathematica Policy Research Inc, December 5 , Princetor.

27 Baumol WJ. An overview of the results on consumption, health and social behaviour. Fournal of Human Resources 1973;9:253-64

28 Kaluzny R. Changes in the consumption of housing services: The Gary Experiment. Fournal of Human Resources 1979;14:496-506.

29 Maynard RA, Murnane RJ. The effects of a negative income tax on school performance: results of an experiment. Fournal of Human Resources 1979;14:463-76.

30 Cain GG, Wissoker DA. A reanalysis of marital stability in the Seattle-Denver Income-Maintenance Experiment. American fournal of Sociology 1990;95:1235-69.

31 Hannan MT, Tuma NB. A reassessment of the effect of income maintenance on marital dissolution in the SeattleDenver experiment. American fournal of Sociology 1990;95: Denver expe

32 Keeley $M$. The effects of negative income tax programs on Fertility. Fournal of Human Resources 1980;:XV:675-93.

33 Elesh D, Lefcowitz MJ. The effects of the New JerseyPennsylvania negative income tax experiment on health and health care utilization. 7 Health Soc Behav 1977;18: 391-405

34 Lefcowitz M, Elesh D. Health and medical care utilisation. In: Watts $\mathrm{H}$, Rees $\mathrm{A}$, eds. The New fersey Income Maintenance Experiment. New York: Academic Press, 1977: 113-28.

35 Kerachsky SH. The health status and medical care utilisation of adults: evidence from the New Jersey experiment. In: follow-up studies using data generated by the New fersey negative income tax experiment. Princeton (NJ): Mathematica Policy Research, Inc, 1976:5.1-5.36.

36 Kerachsky SH. State of health and utilisation of medical care. In: Final Report of the Rural Income Maintenance Experiment. Madison: Institute for Research on Poverty, Experiment.

37 Kerachsky SH. The effects of income maintenance on the medical care utilisation and health status of rural families. Staff Paper. Princeton: Mathematica Policy Research Inc, November, 1978. Report no: SP-78B-03.

38 Kehrer KC. The Gary Income Maintenance Experiment: Introduction. Fournal of Human Resources 1979;14:431-3.

39 Bradbury KL. Non-labor-supply responses to the income maintenance experiments. Discussion. In: Munnell A, ed. Lessons from the income maintenance experiments. Boston: Federal Reserve Bank of Boston, 1987:122-30.

40 Stieger GL, Hoi SW. Income maintenance, medical care utilisation, health status and labor supply: evidence from the Seattle and Denver income maintenance experiments. Technical Memorandum. Menlo Park (CA): SRI International, 15 August 1980. Report no: SD 26.

41 Thoits P, Hannan M. Income and psychological distress: the impact of an income-maintenance experiment. 7 Health Soc Behav 1979;20:120-38.

42 Kehrer BH, Wolin CM. Infant birth weight. Princeton (NJ): Mathematica Policy Research, 1977.

43 Rossi PH, Berk RA, Lenihan KJ. Money, work and crime. New York: Academic Press, 1980.

44 Bradbury KL, Downs A. Do housing allowances work? Washington DC: Brookings Institution, 1981.

45 Bendick M, Jr. Vouchers versus income versus services: an American experiment in housing policy. Fournal of Social Policy 1982;11:365-77.

46 Lafave HG, de Souza HR, Prince PN, et al. Partnerships for people with serious mental illness who live below the poverty line. Psychiat Serv 1995;46:1071-3.

47 Mulrow C. Rationale for systematic reviews. BMF 1994;309: 597-9.

48 Thompson DF. The ethics of social experimentation: the case of the DIME. Public Policy 1981;29:369-98.

49 Roos N. Contrasting social experimentation with retrospective evaluation. Public Policy 1975;23:241-57.

50 Oakley A. Experimentation and social interventions: a forgotten but important history. BMF 1998;317:1239-42.

51 Grossman J. Evaluating social policies: principles and US experience. The World Bank Research Observer 1994;9:15980 .

52 Greenberg D, Shroder M. Digest of the social experiments. IRP Special Report. Madison: Institute for Research on Poverty, May 1991. Report no: 52 .

53 Craig P. Costs and benefits: a review of research on take-up of income-related benefits. Fournal of Social Policy 1991;20: 537-65. 